\title{
Climate Change, Environmental Security and Global Justice
}

\author{
Professor Solomon E. Salako ${ }^{1}$ \\ ${ }^{1}$ Department of Law and Archbishop Desmond Tutu Centre for War and Peace Studies, Liverpool Hope \\ University, Liverpool, United Kingdom \\ Correspondence: Professor Solomon E. Salako, Department of Law and Archbishop Desmond Tutu Centre for \\ War and Peace Studies, Liverpool Hope University, Liverpool, United Kingdom. E-mail: salakos@hope.ac.uk
}

Received: May 4, 2017

doi:10.5539/ilr.v6n1p119
Accepted: May 26, $2017 \quad$ Online Published: August 28, 2017

URL: https://doi.org/10.5539/ilr.v6n1p119

\begin{abstract}
There is an international consensus that climate change is caused by human activities which substantially increase the atmospheric concentration of greenhouse gases.

The ill-effects of climate change are droughts which adversely affect the global poor who are engaged in agriculture; storm surges which destroy local infrastructure, housing and crops; and the rise of sea levels which adversely affect the inhabitants of small island states which could eventually be totally submerged. Military strategists and intelligence analysts are preparing for future conflicts likely to be caused by environmental security issues.

The objects of this article are: (i) to evaluate the ill-effects of climate change as a matter of global justice, (ii) to consider whether future generations have the right not to suffer from the ill-effects of climate change, and if so, (iii) to evaluate the relevant conceptions of global justice, and (iv) to assess critically whether international law provides effective preventive responses to climate change and environmental security threats.

Finally, a monist-naturalist conception of global justice privileging human dignity as one of its guiding principles is proffered as a solution to the problems raised by the mechanisms of dealing with the ill-effects of climate change and the attendant environmental security issues under international law.
\end{abstract}

Keywords: climate change, environmental security, future generations, international law, global justice

\section{Introduction}

The contribution of greenhouse gases to climate change and the attendant environmental problems have been the subject of a broad international consensus for over two decades. The 1985 Vienna Convention was the first treaty to address global atmospheric issues by adopting measures to protect human health and the environment against the adverse effects resulting or likely to result from human activities which adversely affect the ozone layer, that is, a film of $\mathrm{O}_{3}$ molecules (ozone) occurring at altitudes of 25 kilometres over the equator and 15 kilometres over the poles which acts as a shield to ultra violet radiation from the sun (Note 1).

The World Commission on Environment and Development was established in 1983 by the United Nations General Assembly and the authors of its report (the Brundtland Report) coined the term "sustainable development" which has become a popular discourse covering environmental issues from local to global, as well as economic, development, and security issues. The Brundtland Report characterised sustainable development as a process that "meets the needs of the present generation without compromising the needs of future generations to meet their needs" (WCED, 2005). In other words, development is sustainable if it benefits the disadvantaged without disadvantaging the needs of the future. For example, increased agricultural production in developing countries can be achieved through the conversion of grasslands and forests to croplands and the use of nitrogenous fertilisers. However, these changes have the oblique consequence of releasing greenhouse gases which have adverse effect on climate change and lead to land degradation through erosion and salinization of soil.

In this article, we shall discuss the following themes:

(i) Climate change, environmental security and global justice;

(ii) Future generations and the non-identity thesis; 
(iii) Intragenerational and intergenerational obligations and conceptions of global justice;

(iv) The preventive responses of international law to climate change and environmental security; and

(v) The feasibility and desirability of a monist-naturalist conception of global justice.

But, first, let us discuss, in a lexical order, climate change coupled with environmental security as a matter of global justice; and to this we now turn.

\section{Climate Change, Environmental Security and Global Justice}

The ill-effects of climate change caused by the emission of greenhouse gases are (i) droughts, (ii) storm surges which result in flooding which destroys infrastructure, housing and crops; (iii) rise in sea levels leading to contamination of fresh water by sea water and which can also adversely affect small island states such as Tonga, Tuvalu, Kiribarti, the Marshall Islands, Antigua and the Maldives which could eventually be submerged; and (iv) increased temperature which results in an increase in the number of people exposed to malaria, dengue and cholera.

Climate change also raises the issue of environmental security which is one of the seven key components of 'human security' that all individuals are entitled to freedom from fear, freedom from want, and equal opportunity to enjoy all their rights and fully develop their potential (Pearson, 2016). The climate-induced environmental security threats are (i) loss of territorial sovereignty due to rising sea levels, (ii) the problem of climate-induced migration, and (iii) environmental problems such as threat of water crisis which can worsen a pre-existing conflict or create a new conflict (Posci, 2016). For example, long-standing interstate tensions in an era of environmental degradation are potential flashpoints for serious water conflicts in fifty-seven transnational basins in Asia (Chellaney, 2011). These tensions will be discussed later in this excursus.

The ill-effects of climate change, therefore, raise issues of intragovernmental and intergovernmental obligations, thus making climate change a matter of global justice. The pertinent questions are: (i) do future generations have a right not to suffer the ill-effects of climate change? (ii) If so, can we extend principles of justice at domestic level to global justice? But, first, let us discuss the right of future generations not to suffer from the ill-effects of climate change, and to this we now turn.

\section{Future Generations and the Non-Identity Thesis}

Climate change raises the issues of global justice in two ways: (i) that the ill-effects of the emission of greenhouse gases of the past and present generations will be borne by future generations, and (ii) that part of the problems facing present and future generations arise because of the policies of past generations. The pertinent question is: Do future generations have rights? The answer to this question is in the affirmative and the contents of the rights of future generations depend on our conceptions of justice: utilitarianism (the greatest happiness of the greatest number), egalitarianism (justice as fairness à la Rawls) (Note 2), sufficientarianism (meeting the needs of the present generation without compromising the ability of future generations to meet their needs) (Note 3), and libertarianism (the Nozickean entitlement theory of distributive justice based on the historical principles of just acquisition, just transfer and rectification which forbids any redistribution by way of taxation) (Note 4). These conceptions of justice are about the distribution of benefits and burdens within a state. The principles of justice enunciated at domestic level, as we shall see later, become problematic when applied at global level. But, first, let us discuss the objections to granting rights to future generations.

The first objection by Derek Parfit is that the term "right" is inappropriate in any discourse on future people (Parfit, 1987). The second objection is the non-identity thesis which rests on two propositions canvassed by Parfit and Grosseries (Parfit, 1987; Grosseries, 2008b). The first proposition is about causation: that present action may have an impact in the future; this makes it possible to have, in the Hohfeldian sense, a correlative duty to a right that will exist but the reverse option of an alleged duty to a right that did not exist in the past is philosophically problematic (Note 5). The second proposition is that the number of future people is unknown and rights involve quantitative dimensions in forms of budget calculation or natural resources (Grosseries, 2008b).

The two objections that it is inappropriate to ascribe rights to future people and the non-identity thesis are not insurmountable problems. The ascription of rights to present and future generations depends on one's conception of justice: whether it is principle-based, interest-based or communitarian.

John Rawls in A Theory of Justice enunciated a principle-based theory of justice derived from the original position: a position of equality which corresponds to the traditional theory of social contract. The original position is a purely hypothetical situation characterised so as to lead to a conception of justice, that is, it is a counterfactual hypothesis (Rawls, 1999a). In this original position, two principles of justice as fairness are 
proffered:

“(a) Each person has an equal right to the most extensive scheme of equal liberties compatible with a similar scheme for all.

(b) Social and economic inequalities are permissible provided they are (i) to protect the greatest expected benefit of the least disadvantaged; and (ii) attach to positions and offices open to all under conditions of fair equality of opportunity [The difference principle] (Rawls, 1993 and 1999a)."

Rawls in Political Liberalism broached the problem of intergenerational justice. He argues that in order to establish fairness between generations, it is necessary to add to the two principles of justice as fairness, instantiated above, another principle: the "principle of just savings". Since society is a system of cooperation between generations over time, Rawls avers that the principle of just savings is required and that this is the principle that members of any generation would adopt and would want any other generation - past, present or future - to adopt (Rawls, 1993).

The other critique of the non-identity thesis is interest-based. According to Caney, a person has a right to $\mathrm{X}$ when $\mathrm{X}$ is a fundamental interest and the interest is not suffering from the ill-effects of climate change. Caney maintains that if persons have a right not to suffer from the ill-effects of climate change, then the right should apply to those who are alive and those who will be born (Caney, 2006). Another critique of the non-identity thesis is the parent-child model: that we are causally responsible for future generations in the same way as we care for our children, and, as co-owners of the earth, Risse opines that the view that "all human beings have the same claims to original resources and spaces that cannot be constrained by reference to what others have accomplished applies to all human beings regardless of when they live" (Risse, 2012).

If, therefore, the identity of future persons does not undermine the extension of principle - and interest-based arguments to intergenerational obligations, then the conceptions of justice applicable to present and future generations can be classified as principle-driven (Rawls and Nozick), interest-based (Caney) and communitarian (Risse). To these conceptions of global justice we now turn.

\section{Intragenerational and Intergenerational Obligations and Global Justice}

Sustainable development - discussed above - implies equity. Equity is both intragenerational, that is, it seeks to redress the imbalance in wealth and economic development between the developed and the developing countries, and intergenerational in that it seeks to alleviate costs across succeeding generations.

Theories of distributive justice focus on the distribution of benefits and burdens within a state. The question is whether the principles of justice that apply within a state apply to global justice.

Global climate change raises the questions of distributive justice, that is, the questions of intergenerational justice: granting rights to future generations and the adaptation of domestic principles of justice to the global environmental problems we face. The adaptation of domestic principles of justice to global justice must be broached. It has been suggested that Rawls's position could be developed to address problems of global justice (Beitz, 1999; Buchanan, 2000 and Pogge 2001). This suggestion bristles with practical problems as we can gather from a critical analysis of Rawls's theory of justice as fairness in A Theory of Justice, Political Liberalism and The Law of Peoples (Rawls, 1993, 1999a and 1999b).

The purpose of Rawls's A Theory of Justice and Political Liberalism is to show how a liberal society might be possible and that of The Law of Peoples is to show that a World Society of liberal and non-liberal (but decent) peoples might be possible. (Rawls chose "peoples" rather than "states" in his reflections because liberal democratic and decent peoples are actors in the World Society of Peoples just as citizens are actors in a domestic society (Rawls, 1999b).) In The Law of Peoples, Rawls applies the original position - the second time - to the international sphere, that is, a World Society of Peoples comprising well-ordered societies, liberal societies and hierarchical (or decent) societies.

Rawls suggests that liberal rights discussed in his first principle of distributive justice should be regarded as human rights enforceable in liberal and non-liberal (but decent) societies. Rawls's second principle of distributive justice, the difference principle, applicable within different societies but not among them drops out of the picture because, according to Rawls, a world government is not feasible. Rawls, like Kant, feels that a world government to enforce the difference principle would either be "a global despotism" or "a fragile empire torn by frequent civil strife as various regions and peoples tried to gain their political autonomy" (Note 6). So Rawls's difference principle is not global in its reach. And yet, The Law of Peoples is designed to address problems that arise in the contemporary globalized world such as unjust war, religious persecution and the denial of liberty of conscience, starvation and poverty and to enunciate principles of foreign policy for well-ordered 
societies, that is, liberal and non-liberal but decent societies.

Cosmopolitans such as Beitz, Buchanan and Pogge argue that for the same reason that parties agree to the difference principle in domestic society, the global principle should be the difference principle. For Beitz and Pogge, the basic structure comprises regional and international agreements such as GATT, WTO, NAFTA and various treaties governing currency exchange mechanism (Buchanan 2000; Pogge 2001a; Pogge 2001b). Beitz's position embodies two levels of international society: the domestic and international levels. While the domestic (i.e., the state) level societies have primary responsibility for their people, the international level establishes and maintains the background conditions applicable to state level societies (Beitz, 1999).

Communitarians challenge the liberal/cosmopolitan emphasis on individual autonomy for closing of considerations of value that individuals find in their culture and communal practices and traditions. Charles Taylor opines that "since the free individual can only maintain his identity within a society/culture of a certain kind, he has to be concerned about the shape of his society/culture as a whole" (Taylor, 2001). The cosmopolitan theories, from a communitarian perspective, are not only presumptuous but also ethnocentric. As Hill stated:

"[T]hroughout history powerful groups have tended to persecute, exploit and try to dominate weaker groups, sometimes with open enmity but often in the name of universal values" (Hill, 2000).

Since Rawls's theory of justice as fairness lacks a theory of environmental justice and the adaptation of Rawls's difference principle at global level is problematic, various theories of global justice addressing the issue of future generations have been proffered. One of such is Matthias Risse's collective ownership of the earth as a ground of justice or what he calls "internationalism" or "pluralist internationalism" (Risse, 2012). A theory of justice based on collective ownership of the earth is an old way of thinking in moral and political philosophy attributed to seventeenth century philosophers such as Hugo Grotius, Samuel Pufendorf, John Locke and others who regarded the earth as the common heritage of humankind (Note 7). The view that God had given the earth to humankind is applied in international law to the high seas, the ocean floor, Antarctica and the outer space. Risse cites Marx's position in Capital, Volume 3, that:

"[Human beings] are not the owners of the globe. They are only its possessors, its usufructuaries, and live boni patres familias, they must hand it down to succeeding generations in an improved condition" (Marx, 1971).

This statement opposes Grotius's view of the matter. For Marx, each generation has an obligation to the next to hand down this planet in an improved condition; for Grotius, there are no duties to future generations. Risse argues that generations of humans occupy the earth successively and that throughout history many societies have recognised duties towards future generations. The ownership approach, Risse concludes, does not generate strong duties to future generations but recognises that "some of the duties that this generation has to future generations concern the preservation of climate conditions hospitable to human life" (Note 8). (A variant of the ownership approach is the common concern of mankind which we shall discuss later in this excursus (Trindade, 2010).)

The positions taken in the cosmopolitan/communitarian debate, discussed above, require a pragmatic reconciliation which must take cognisance of the world order. The world order after the Peace of Westphalia of 1648 is based on state sovereignty and the horizontal equality of all states. Consequently, the interstate system is based on communitarian principles, that is, shared traditions within communities which vary from state to state, and not cosmopolitan principles based on universal values or common humanity. From the perspective that the interstate system is based on communitarian principles, we critically assess the preventive responses of international law to climate change and environmental security.

\section{A Critical Assessment of the Preventive Responses of International Law to Climate Change and Environmental Security}

The international law responds to climate change and environmental security issues in four ways: (i) through the instruments present in the climate change regime; (ii) the securitization of climate change by recasting climate change as a threat to international peace and security and using the mechanisms of the UN Charter provided in Chapter VII; (iii) through international human rights law; and (iv) application of existing principles and precedents in international environmental case law such as the trilogy of Trail Smelter Case (Note 9), Case Concerning the Territorial Jurisdiction of the International Commission of the River Oder (Note 10) and Lac Lanoux arbitration (Note 11).

\subsection{Instruments Present in the Climate Change Regime}

The genesis of the climate change regime has been traced to the Climate Change Convention 1992 but an 
acrimonious debate pre-dates the Convention. In 1988, the World Meteorological Organisation and the United Nations Environmental Programme established the Intergovernmental Panel on Climate Change (IPCC) which was charged with assessing the risks of climate change caused by human activities. Although the IPCC stated in the first of its five reports in 1990 that "the balance of evidence suggests that there is a discernible human influence on climate change", it was in the fifth assessment report released in 2013 that it was stated that global warming is unequivocal and that the likelihood that humanity is causing it is 'extremely likely', which meant, 95-100 per cent certainty" (IPCC, 1990 and 2013). This statement was not enough for climate change sceptics right wing politicians or members of the conservative think tanks in the United States - who refuse the broad consensus within the international community of relevant scientists on the following grounds: (i) that the pursuit of environmental protection involves government action which is repugnant to libertarianism (à la Nozick discussed above), (ii) that growing concern about global warming and the possibility of social change resulting from such efforts pose a threat to the entire 'American way of life', and (iii) that, in any case, the evidentiary basis of global warming is weak (McCright and Dunlap, 2003).

In spite of this persistent denial, the five phases of the evolution of the climate change regime are:

(i) the establishment of the United Nations Framework Convention on Climate Change 1992 (UNFCCC 1992) (Note 12);

(ii) the 1997 Kyoto Protocol (Note 13);

(iii) the Copenhagen Accord 2009 (Note 14);

(iv) the Paris Agreement 2015 (Note 15); and

(v) the Marrakech Proclamation 2016 (Note 16).

The UNFCCC signed at the United Nations Conference on Environment and Development in Rio in 1992 established commitments to stabilise greenhouse gas concentration and a financial mechanism and commitment by developed country parties to provide financial resources for meeting certain incremental costs and adaptation measures.

The State Parties to the Kyoto Protocol 1997 agreed to reduce their collective emissions of six greenhouse gases (carbon dioxide, methane, nitrous oxide, hydro fluorocarbon,per fluorocarbon and sulphur hexafluoride) by at least five percent by 2008 - 2012 (Article 3). The United States, a country with four percent of the world's population, accounts for 25 percent of the world's carbon dioxide emissions but refused to ratify the Protocol for reasons stated above.

The Copenhagen Accord 2009 is not a legally binding document but a political agreement by a group of 28 countries including all the world's major economies to limit climate change to no more than two degrees Celsius and a "pledge and review" for mitigation commitment or actions by both developed and developing countries. US President Barack Obama and Secretary of State Hillary Clinton attended the Copenhagen Conference.

The Paris Agreement 2015, in its preambular statements, recognised (i) the Parties to the Agreement as Parties to the UNFCCC, (ii) the specific needs and particular circumstances of developing country Parties, and (iii) the fundamental priority of safeguarding food security and ending hunger and the particular vulnerabilities of food production systems to the adverse impacts of climate change.

The purpose of the Paris Agreement is to strengthen the global response to the threat of climate change in the context of sustainable development and make efforts to eradicate poverty and limit average temperature to well below two degrees Celsius and to limit temperature increase to 1.5 degrees Celsius (Article 2 (1)). It must be noted that Article 21 of the Paris Agreemant provides that the Agreement shall enter into force on the thirtieth day after the date on which at least 55 Parties to the Convention accounting in total for at least an estimated 55 percent of the total greenhouse gas emission have ratified, accepted or approved or acceded to it. (As at the time of writing 135 of 197 Parties to the UNFCCC have ratified the Agreement (Note 17). A Party to the Agreement may withdraw from the Agreement after three years of its entering into force and any Party that withdraws from the UNFCCC shall also withdraw from this Agreement (Article 28).

The proffered withdrawal of the United States from the Paris Agreement by President Donald J. Trump will not affect the implementation of the Paris Agreement. The Marrakech Climate Change Conference of 2016 demonstrated that the implementation of the Agreement is underway and the spirit of global cooperation on climate change continues.

The problem with the instruments of global climate change regime is that neither the UNFCCC 1992 nor the Kyoto Protocol includes any provisions for those who will be directly affected by climate change, and, what is 
more, the Copenhagen Accord 2009 is not legally binding and fails to provide a "binding" commitment on the mitigation of climate change. Thus, the protection of those adversely affected by climate change must now be considered under the security mechanisms of the UN Charter, international law of human rights and principles and precedents of international environmental law. But, first, let us evaluate the securitisation of climate change.

\subsection{Mechanisms of the UN Charter - Chapters VI and VII}

Climate change threatens water, food security, coastal populations and small island states; creates a new breed of refugees, environmental refugees; and raises tensions and triggers conflicts. It has been suggested that the conflict in Darfur was partly driven by climate change. Another source of conflict perceived by military strategists and intelligence analysts is water stress or water security (Brown,et al,2007). Shapiro opines that the construction of dams on the upper reaches of Mekong River (in China) and Salween River (in China) which affect the water supply of riparian states of Laos, Cambodia, Thailand and Myanmar has the potential for conflict (Shapiro, 2016).

The recasting of climate change as a threat to peace and security is attributed to six documents:

(i) The 1982 UN General Assembly Resolution, World Charter for Nature, maintains, in a preambular statement, that "competition for scarce resources creates conflict, whereas the conservation of nature and natural resources contributes to justice and the maintenance of peace cannot be achieved until mankind learns to live in peace and forsake war and armament" (Note 18).

(ii) The Brundtland Report highlighted the nexus between environmental problems and international security (Note 19).

(iii) The Rio Declaration on Environment and Development 1992, principle 6 states that: States shall resolve all their environmental disputes peacefully and by appropriate means in accordance with the Charter of the United Nations (Note 20).

(iv) The United Nations Millennium Declaration 2000, paragraph 9, states: We resolve therefore to make the United Nations more effective in monitoring peace and security by giving it resources and tools it needs for conflict prevention, peaceful resolution of disputes, peace-building and reconstruction (Note 21).

(v) The Johannesburg Declaration on Sustainable Development 2002 noted, in paragraph 35: We commit ourselves to work together, united by a common determination to save our planet, promote human development and achieve universal prosperity and peace (Note 22).

(vi) In The Madrid Declaration on Environment and Security 2007, the Ministerial Council of the Organisation for Security and Co-operation in Europe noted:

"Environmental degradation, including both natural and man-made disasters, and their possible impact on migratory pressures, could be potential additional contribution to conflict. Climate change may magnify the environmental challenges." (Note 23).

The pertinent question is whether the UN Security Council should deal with climate change, and, if so, whether the UN Charter mechanism provided for in Chapter VII of the Charter should apply. Those who support the securitisation of climate change (France and Germany) argue that the securitisation of climate change is part of conflict prevention which is essential when dealing with peace and security. Some of the vulnerable island states went further by arguing that climate change is already a security issue for them and that the Security Council should not only debate the problem but also act on it as soon as possible. The leading developing countries such as China, India, South Africa and Brazil and the G77 countries ( a group of 77 developing countries established on 15 June 1964 to promote its members' economic interests and enhance their negotiating capacity in the United Nations ) argue that climate change is not a security issue but a sustainable development issue (Sindico, 2007).

The security threat to the small island states are real and imminent and global justice in the sense of common concern for mankind demands that, in the absence of any solution under the climate change regime discussed above and recognising that the international human rights - discussed below - are problematic, the UN Security Council must act. The question is: How should the UN Security Council proceed?

First, Article 1(1) of the UN Charter states that one of the purposes of the United Nations is:

"to bring about by peaceful means, and in conformity with the principles of justice and international law, 
adjustment or settlement of international law or situations which might lead to a breach of peace."

Article 1(1) of the Charter must be read conjunctively with Article 2(3) which obliges Member States to "settle their disputes by peaceful means in such a manner that international peace and security, and justice, are not endangered."

Second, we must consider Chapters VI and VII of the UN Charter. Although Chapter VI of the UN Charter empowers the Security Council to make various types of recommendations for peaceful settlement of dispute, the relevant section of the Charter to inhabitants of small island states who are likely to be climate-induced or environmental refugees is Chapter VII of the Charter entitled "Action with respect to threats to the peace, and acts of aggression". Terms such as "threats to the peace" and "breaches of the peace" are not defined in the Charter, but three Articles of Chapter VII - Articles 39 to 41 - are useful. Article 39 provides:

"The Security Council shall determine the existence of any threat to the peace, breach of the peace, or act of aggression and shall make recommendations, or decide what measures shall be taken in accordance with Articles 41 and 42, to maintain international peace and security."

Article 40 deals with provisional measures to be adopted by the Security Council while Article 41 provides for non-military enforcement action. Since climate change is being recast as a threat to international peace and security, Malanczuk opines that "threat to peace" in the sense of Article 39 means "whatever the Security Council says is a threat to peace, which is a political decision and as a matter of principle, not subject to legal evaluation" (Malanczuk, 2009). In a similar vein, Shaw describes Article 39 as constituting "a safety net for Security Council action where the conditions needed for breach of the peace or act of aggression do not appear to be present" and observes that "threat to peace" is "the category which has marked a rapid evolution as the perception as to what amounts to a threat to international peace and security has broadened" (Shaw, 2014). In other words, the mechanisms of Chapter VII of the UN Charter apply to environmental security.

We must now consider the universal and basic human rights of those affected by climate change, especially the rights of the inhabitants of small island states who could become environmental refugees.

\subsection{International Human Rights Law}

The protection of environmental or climate change refugees under international human rights law bristles with definitional and practical problems. The definition of a refugee as set out in the United Nations Convention Relating to the Status of Refugees 1951 requires (i) a fear, (ii) that is well-founded, (iii) of prosecution, (iv) based on reason of race, religion, nationality, membership in particular social group or political opinion (Note 24). The inhabitants of the small island states do not meet this definition because "climate change" and "environment" are not recognised as accepted grounds. The 1967 Protocol Relating to the Status of Refugees did not review the substantive content of the definition of "refugees" (Note 25). The 1990 International Convention on the Protection of the Right of All Migrant Workers and Members of their Families protects migrant workers and their families (Note 26). Environmental refugees were not included in the 1990 Convention. The International Organisation on Migration has proffered a definition of "environmental migrants" as:

"persons or (a) group of persons who, for compelling reasons of sudden or progressive changes in the environment that adversely affect their lives or living conditions, are obliged to leave their habitual homes, or choose to do so, either temporarily or permanently or who move either within their country or abroad" (Note 27).

It has been suggested that the 1951 Refugees Convention should be extended to embrace this new definition. The rise of populism in the United States and Europe and the resistance towards refugees preclude the extension of the Refugee Convention to climate or environmental refugees in the foreseeable future. However, these refugees can avail themselves of their right to life, liberty and the security of the person under Article 3 of the Universal Declaration of Human Rights 1948 (UNDHR) and Article 6 of the International Covenant on Civil and Political Rights 1966 (ICCPR) and right to food and water under Article 25 of the UNDHR 1948 and Article 11 of the International Covenant on Economic, Social and Cultural Rights 1966 (ICESCR). The right to water (that is, clean drinking water) was recognised by the United Nations Human Rights Committee in 2002 (Note 28).

The problem is that while many developing and developed nations ratified most of the human rights documents, the United States ratified the ICCPR 1966 with five reservations, five understandings and one proviso (Carpenter, 2000). China ratified the ICESCR 1966 but did not ratify the ICCPR 1966 because the civil and political rights promulgated are alien to Asian values which are based on order, discipline and loyalty rather than liberty or freedom (Sen, 1999).

We must now move from international human rights instruments to principles and precedents of international 
environmental law.

\subsection{Principles and Precedents of International Environmental Law}

Three causes celèbres are worthy of note, viz (i) the Trail Smelter case, (ii) the Case Concerning the Territorial Jurisdiction of the International Commission of River Oder, and (iii) the Lac Lanoux arbitration.

In the Trail Smelter case, the pollutant in issue was sulphur dioxide $\left(\mathrm{SO}_{2}\right)$ produced by high-sulphur content of fossil fuel (coal and oil) which combined with rain formed acid rain - a harmful respiratory tract irritant. The dispute which went to arbitration was the emission of sulphur dioxide from one smelter in Canada which caused damage in the State of Washington in the United States. The Tribunal applied the principle of international law that "no state has the right to use or permit the use of territory in such a manner as to cause injury by fumes in or to the territory of another or properties of persons therein, when the case is of serious consequence and the injury is established by clear and convincing evidence" (Note 29). In this case, the community of interest principle, a natural law concept, was applied.

In 1929, in the Case Concerning the Territorial Jurisdiction of the International Commission of the River Oder, the Permanent Court of International Justice (PCIJ) held that the utilisation of rivers including their flow was subject to international law. The PCIJ noted that the "community of interests" in a navigable river was the basis of a common legal right, the essential features of which were (i) equality of all riparian users in the use of the whole course of the river, and (ii) the exclusion of any preferential privilege of any one riparian user (Note 30).

Seventy years later in Kasikili/Sedudu Island, the International Court of Justice extended the common interest principle to non-navigable rivers (Note 31). Again, in Lac Lanoux arbitration (France v Spain), a proposal by the French Government to authorise the construction of a barrage to channel water through hydro-electric plant, thereby diverting approximately 25 percent of the flow of Carol River before returning the same amount to the river prior to its use by farmers in Spain was brought before an arbitral tribunal. The tribunal held that the proposed work did not constitute an infringement but stated that their conclusion would have been different if the proposed works would pollute River Carol or change the chemical composition, temperature or characteristics of the waters in such a way as to injure other riparian users (Note 32).

The purpose of citing the above-mentioned cases on the principle of community of interests is to highlight the elasticity of the principle and to show that it could be used to develop new principles for climate change and its attendant environmental problems such as the environmental or climate refugee issue, deforestation, sustainable development, water stress and the resolution of climate-induced conflicts instantiated in section 5.2 above.

\section{The Feasibility and Desirability of a Monist-Naturalist Conception of Global Justice}

From the foregoing analysis of treaties on climate change from the UNFCCC 1992 to the Marrakech Proclamation 2016, it is safe to assert that the protection of present and future generations from the ill-effects of climate change is a norm of international law. I use the term "treaty" here as meaning:

"any international agreement in written form, whether embodied in a single instrument or more related instruments, whether its particular designation (treaty, convention, protocol, covenant, concordat, exchange of notes, agreed minute, memorandum of agreement, modus vivendi or any other appellation), concluded between two or more States or other subjects of international law and governed by international law" (Note 33).

The question is: what is the conception of justice underpinning the international instruments on climate change and its attendant environmental problems? One candidate for such a conception of global justice is John Rawls's A Theory of Justice as amended by Political Liberalism, extrapolated by The Law of Peoples discussed above and adopted by cosmopolitans such as Beitz, Buchanan and Pogge. The first problem is that Rawls's difference principle applies within states and not among states because a world government to enforce such a principle at global level is not feasible for reasons stated by Rawls himself (Note 34).

The second problem with Rawls's conception of justice as fairness in a multicultural society is that it is justified by an overlapping consensus (Note 35). This justification is not supported by empirical evidence. But that is not all. The problem with Rawls's translocation of Western liberalism to non-liberal (but decent) societies is the clash of civilizations and the clash of cultures. In The Clash of Civilizations and the Remaking of the World Order, S. P. Huntington argues that " $(\mathrm{t})$ he philosophical assumption underpinning values, social relations, customs, and overall outlook on life differs significantly among civilisations" (Huntingdon, 2002). Rawls's eighth principle of foreign policy in the World Society of liberal and non-liberal (but decent) Peoples enunciated in The Law of Peoples which states that "peoples have a duty to assist other peoples living under unfavourable conditions to prevent their having a just or decent regime" is a principle of international ethics, not a principle of 
global justice. For the above reasons, the Rawlsian paradigm is inapt for a conception of global justice underpinning climate change and the attendant environmental problems. A conception of justice with global reach must privilege, as one of its guiding principles, human dignity defined in Pope John Paul II's Encyclical Letter Centessimus Annus as follows:

"[B]efore the right which man acquires by his own work, there exist rights which do not correspond to any work he performs but which flow from his essential dignity as a person" (Note 36).

The starting-point for articulating a conception of global justice privileging human dignity as a guiding principle is Hill's philosophy and anthropology of human dignity. In his polemical writings, Hill contends that we live in a world where interests are diverse and often conflicting and human beings are worthy of respect "regardless of how their values differ and whether or not we disapprove of what they do" (Hill, 2000). He identifies four basic attitudes of human dignity in a multi-cultural society: (i) that people in different cultures have different legal systems, interpersonal relationships, tastes and aspirations; (ii) that people identify themselves and their projects in cultural content; (iii) that there is a tendency towards ethnocentricity on cross-cultural issues; and (iv) that cultures and subcultures are unequal (Note 37).

Mindful of the four basic attitudes to human dignity described by Hill, a monist-naturalist conception of global justice where the norms of municipal and international legal orders are not derived from the same Grundnorm (a basic norm) as in Kelsen's pure theory of law is proffered (Kelsen, 1967). The norms of international law are subject to a communitarian conception of global justice privileging human dignity as one of its guiding principles. A communitarian conception of justice underpins natural law doctrines such as common ownership of earth, common concern of mankind and the principle of common interest discussed above. This communitarian conception of justice is based on a system of rights $a ̀$ la Unger which preserves minimal qualities of well-being and existence worldwide and includes the following rights:

(i)

immunity rights - autonomy and human dignity - which are to be given priority unless critical morality (i.e., the morality by which every human institution including positive morality itself is assessed) dictates otherwise;

(ii) rights of powerful groups that have ossified and are inimical to the interests of weaker groups must be subjected to destabilisation rights;

(iii) claims to divisible portions of market rights must be guaranteed (Note 38); and

(iv) solidarity rights - rights arising from mutual reliance such as contract, tort and trust must be protected (Unger, 1987).

The monist-naturalist conception of global justice is not only feasible but also desirable as a solution to the philosophical, cultural and ethical problems raised by any legal framework for societies with different philosophical and sociocultural backgrounds.

\section{Summary and Conclusions}

Climate change is responsible for several environmental problems: droughts which are felt by the global poor who are employed in agriculture; raised sea-levels and storm surges which are devastating to agriculture, increase in migration and social tension, decreased tourism, and the destruction of local infrastructure; the eventual submergence of small island states; contamination of freshwater sources by sea-water; and the increased temperatures which result in an increase in the number of people exposed to malaria, dengue and cholera. Therefore, climate change is a matter of global justice.

It is true that there is a broad international consensus that climate change is caused by the emission of greenhouse gases and the conversion of natural grassland and forests to croplands. The two countries responsible for the highest emission of greenhouse gases - the United States and China - should lead the concerted effort to eliminate the ill-effects of climate change. While China is proactive in reducing the emission of greenhouse gases and is the world leader in solar energy, future American leadership is highly unlikely. The proffered withdrawal of the United States from the Paris Agreement and the rolling back of climate protection in the US by President Donald J. Trump will not affect the implementation of the Agreement as demonstrated by the Marrakech Proclamation 2016 (Note 39).

The responses of international law to climate change and environmental security have been haphazard. We have a cluster of legally binding provisions (ICCPR 1966, UNFCCC 1992, the Kyoto Protocol 1997 and the Paris Agreement 2015); non-binding provisions (the ICESCR 1966 and the Copenhagen Accord 2009); political norms (the mechanisms of Chapter VII of the UN Charter); and principles and precedents of international 
environmental law such as the Trail Smelter case and the Lac Lanoux arbitration. There is also a striking omission: the term "environmental refugees" is not in any extant treaty (as liberally defined above) (Note 40). And, what is more, the ICCPR 1966 is a "toothless tiger"; the United States ratified the Convention with five qualifications, five understandings and one proviso; China did not ratify it (Carpenter, 2000).

Natural law doctrines such as common ownership of earth and common concern of mankind and the principle of community of interests which raise issues of global justice are pressed into service when promulgating legal frameworks for societies with different philosophical and sociocultural backgrounds. Since the interstate system grafted on a world order developed after the Westphalian Peace of 1648 is based on communitarian principles and not cosmopolitan principles (ie, universal values and common humanity), the only defensible conception of global justice underpinning the climate change regime and international environmental law is a monist-naturalist conception of global justice privileging human dignity as one of its guiding principles. This conception of justice underpins the Council of Europe Convention on Human Rights and Biomedicine (ECHRB) (Note 40). The ECHRB is a regional instrument which has a wide territorial application because non-EU states which took part in its preparation - Australia, Canada, the Holy See, Japan and the United States - may sign the Convention (Article 33). The monist-naturalist conception of global justice not only protects present and future generations from the ill-effects of climate change, but also serves as a tool for promulgating legal frameworks for societies with different philosophical and sociocultural backgrounds.

\section{Acknowledgements}

This paper was presented on $3^{\text {rd }}$ May 2017 as the author's Professorial Fellow Lecture at Liverpool Hope University, United Kingdom. I thank those present for their comments. Thanks also to the anonymous referees for their informed and constructive comments.

\section{References}

Beitz, C. R. (1979/1999). Political Theory and International Relations (pp. 214-215). Princeton, NJ: Princeton University Press.

Brown, O., Hamil, A., \& McLeman, R. (2007). Climate Change as the 'new' security threat: implications for Africa. International Affairs, 83(6), 1141-1154. https://doi.org/10.1111/j.1468-2346.2007.00678.x

Buchanan, A. (2000). Rawls' Law of Peoples. Ethics, 110, 706.

Caney, S. (2006). Cosmopolitan Justice, Rights and Global Climate Change. Canadian Journal of Law and Jurisprudence, 19(2), 255-278. https://doi.org/10.1017/S0841820900004100

Carpenter, K. D. A. (2000). The International Covenant on Civil and Political Rights: A Toothless Tiger? North Carolina Journal of International Law and Commercial Regulations, 26, 1-55.

Chellaney, B. (2011). Water: Asia's New Battleground (p. 297). Washington DC: Georgetown University Press.

Grosseries, A. (2008a). Theories of intergenerational justice: a synopsis. Surveys and Perspectives Integrating Environment and Society, 1, 61-69.

Grosseries, A. (2008b). On Future Generations' Future Rights. Journal of Politics and Philosophy, 16(4), 464-474. http://dx.doi:10.1111/j.1467.9760.2008.00323.x

Hill, T. E. (2000). Respect, Pluralism and Justice (pp. 81-82). Oxford: Oxford University Press. https://doi.org/10.1093/0198238347.001.0001

Hohfeld, W. N. (1966). In W. W. Cook (Ed.), Fundamental Legal Conceptions as applied in Judicial Reasoning. New Haven. Yale University Press.

Huntington, S. P. (2000). The Clash of Civilizations and the Remaking of World Order (pp. 28-29). London: Simon and Schuster.

IPCC. (1990). International Panel on Climate Change. Climate Change, 3 vols. Cambridge: Cambridge University Press.

IPCC. (2013). International Panel on Climate Change. The Physical Science Basis. Cambridge: Cambridge University Press.

Kelsen, H. (1967). The Pure Theory of Law, trans. Max Knight (pp. 4-15). Berkeley: University of California.

Malanczuk, P. (2009). Akehurst's Modern Introduction to International Law (7th ed.), London: Routledge.

Marx, K. (1971). In F. Engels (Ed.), Capital (Vol. 3, p. 776). London: Lawrence and Wishart. 
McCright, A. M., \& Dunlap, R. E. (2003). Defining Kyoto: The Conservative Movement's Impact on US Climate Change Policy. Social Problems, 50(3), 348-373. https://doi.org/10.1525/sp.2003.50.3.348

Nozick, R. (1974). Anarchy, State, and Utopia. Oxford: Blackwell.

Parfit, D. (1987). Reasons and Persons (pp. 335-365). Oxford: Clarendon Press.

Paul II, J. (Pope) (1991). Centessimus Annus (p. 16). London: Catholic Truth Society.

Pearson, J. (2016). Human Security versus Environmental Security: At Legal Loggerheads. In M. E. Footer, J. Schmidt, N. D. White, \& L. Davies-Brights (Eds.), Security and International Law (p. 44). Oxford: Hart Publishing.

Pogge, T. (2001a). Rawls on international justice. The Philosophical Quarterly, 51, 246-253. https://doi.org/10.1111/j.0031-8094.2001.00228.x

Pogge, T. (2001b). Priorities of Global Justice. Metaphilosophy, 32, 6-24. https://doi.org/10.1111/1467-9973.00172

Posci, M. (2016). Climate Change as a Threat to International Security. In M. E. Footer, J. Schmidt, N. D. White, \& L. Davies-Bright (Eds.), Security and International Law (pp. 341-364). Oxford: Hart Publishing.

Rawls, J. (1993). Political Liberalism. New York: Columbia University Press.

Rawls, J. (1999a). A Theory of Justice (1972; Revised Edn.). Oxford: Oxford University Press.

Rawls, J. (1999b). The Law of Peoples. Cambridge, MA: Harvard University Press.

Risse, M. (2012). On Global Justice (pp. ix, 89-90 and 177). Princeton, NJ: Princeton University Press.

Sen, A. (1999). Development As Freedom (p. 23). Oxford: Oxford University Press.

Shapiro, J. (2016). China's Environmental Challenges (pp. 3 and 4). Cambridge: Polity.

Shaw, M. N. (2014). International Law (7th ed.) (pp. 898 and 899), Cambridge: Cambridge University Press.

Sindico, F. (2007). Climate Change: A Security (Council) Issue? Carbon and Climate Change Review, 1, 29-34. https://doi.org/10.21552/CCLR/2007/1/8

Taylor, C. (2001). Atomism. In S. Avineri, \& A. De-Shalit (Eds.), Communitarianism and Individualism (p. 47). Oxford: Oxford University Press.

Trindade, A. A. C. (2010). International Law for Human Kind: Towards a New Jus Gentium (pp. 327-333). Leiden: Martinus Nijhoff. https://doi.org/10.1163/ej.9789004184282.i-728

Unger, R. M. (1987). False Necessity: Anti-Necessitarian Social Theory in the Service of Radical Democracy (pp. 508-537). Cambridge: Cambridge University Press.

WCED. (2005). World Commission on Environment and Development, Our Common Future. Oxford: Oxford University Press.

\section{Notes}

Note 1. Convention for the Protection of the Ozone Layer (Vienna) 22 March 1985, in force 22 September 1988, 26 ILM. 1529 (1985) 1985 Vienna Convention).

Note 2. See Rawls (1993); Rawls (1999a); and Rawls (1999b).

Note 3. See Grosseries (2008a).

Note 4. See Nozick (1974).

Note 5. See Hohfeld (1966).

Note 6. See Rawls (1999b: 36).

Note 7. See Risse (2012: 89 - 90).

Note 8. See Risse (2012: 167, 169 and 186).

Note 9. Trail Smelter arbitration (United States v Canada) (1941) 35 American Journal of International Law 716, 9 ILR 317.

Note 10. Judgement No. 16, PCIJ (1929) Ser. A. No. 23, 27.

Note 11. Lac Lanoux arbitration (1957) 24 International Law Reports 101. 
Note 12. United Nations Framework Convention on Climate Change (UNFCCC 1992); www.unfccc.int/essential-background/convention/background/items/1349.php

Note 13. Kyoto Protocol to the United Nations Convention on Climate Change, www.unfccc.int/kyoto-protocol/items/2830.php

Note 14. Copenhagen Climate Conference in December 2009, www.czes.org/international/negotiations/cop-15/summary

Note 15. Paris Agreement on Climate Change 2015, unfccc.int/parisagreement/items/9845.pdf

Note 16. Marrakech Climate Change Conference 2016, Marrakech action proclamation.pdf.

Note 17. United Nations Climate Change Secretariat, Progress trackers, www.unfccc.int/files/paris-agreement/applications/pdf/pa-progress-tracker-28116.pdf (accessed on 19.3.2017).

Note 18. UNGA Resolution A/RES/37/7.

Note 19. Supra, note 2.

Note 20. UN Doc. A/CONF. 151/26 (Vol. 1).

Note 21. UNGA resolution A/RES/55.2.

Note 22. UN Doc. A/CONT. 199/20.

Note 23. OSCE, MC.DOC 4/07, 30 November 2007.

Note 24. Convention Relating to the Status of Refugees, available at http://www2.ohchr.org/english/law/refugees.htm

Note 25. The 1967 Protocol Relating to the Status of Refugees, available at http://www2ohchr.org/english/law/protocolrefugees.htm

Note 26. The International Convention on the Protection of All Migrant Workers and their Families 1990, available at https://www2.ohchr.org/english/law.cmw.htm

Note 27. IOM (International Organisation on Migration). Migration and Climate Change, IOM Migration Research Series No $31 \quad$ (p.15), available at Migration-and Climate Change_-_Migration_Research_Series_No_31.pdf

Note 28. UN Economic and Social Council (ECOSOC) Committee on Economic, Social and Cultural Rights, $29^{\text {th }}$ session, General Comments No. 15: The Right to Water, para. 1, UN Doc. E/C. 12/2002/11 (January 20, 2003), available at http://www2.ohchr.org/english/issues/water/docs/CESCR_CC_15.pdf

Note 29. Trail Smelter arbitration (United States v Canada) (1941) 35 American Journal of International Law 716; 9 ILR 317.

Note 30. Judgement No. 16, PCIJ (1929) Ser. A. No. 23, 27.

Note 31. (1997) ICJ Reports 7, para. 85.

Note 32. (1957) 24 International Law Reports 101.

Note 33. Yearbook, I.L.C., 1962, ii, 161.

Note 34. Supra, note 6.

Note 35. See Rawls (1993: Lecture 4 ).

Note 36. See Paul (1991: 16). See also Article 1 of the Universal Declaration of Human Rights 1948 which provides that "All human being are born free and equal in dignity and rights. They are endowed with reason and conscience and should act towards one another in a spirit of brotherhood."

Note 37. Hill (2000: 81).

Note 38. See, for example, $R v$ Independent Television Commission, ex parte Danmark 1 Ltd (2001) 1 WLR 1604, HL, where pursuant to Article 3a (3) of the Council Directive 89/552/EEC (generally known as the Television Without Frontiers Directive) a broadcaster who obtained exclusive rights to cover a public event of high importance was prevented from effectively depriving a large part of the public in one state or more of the public in more state or more of the opportunity of following it on television.

Note 39. Supra, note 16.

Note 40. Council of Europe Convention for the Protection of Human Rights and Dignity of the Human Being 
with regard to the Application of Biology and Medicine: Convention on Human Rights and Biomedicine, available

http://rm.coe.int/COERMPublicCommonSearchService/DisplayDCTMContent?document-Id=090000168007cf9 8

\section{Copyrights}

Copyright for this article is retained by the author(s), with first publication rights granted to the journal.

This is an open-access article distributed under the terms and conditions of the Creative Commons Attribution license (http://creativecommons.org/licenses/by/4.0/). 